\title{
Influence of genetic and paratypical factors on lamb's resistance
}

\author{
S.Ch. Kazanchev, A.M. Unazhokov, O.O. Getokov ${ }^{*}$, R.Z. Abdulkhalikov and \\ M.G. Tleinsheva
}

Kabardino-Balkarian State Agrarian University named after V.M. Kokov, 360030, V.I. Lenin 1 "v", KBR, Nalchik, Russia

\begin{abstract}
The article studies the influence of the frequency and time of consumption of colostrum on the immunobiological reactivity of lambs obtained from mothers of the same age, selected according to the principle of analogues. It has been established that first lambers (9-16 months) with intensive rearing and abundant feeding have an average level of resistance of the organism and its indicators are characterized by stability. The offspring obtained from these first lambers (experimental group) in terms of the level of immune parameters are not inferior to their peers obtained from the ewes of the control group. Lambs from first lambers in terms of lysozyme activity of blood serum, immunoglobulin content are superior to their peers from older ewes (the difference is not statistically significant, $\mathrm{P}>0.05$ ). At the same time, young animals regardless of the age of their mothers have the same vitality. The lambs' mortality from birth to wean in the experimental and control groups was approximately the same - 7.2 and $8.0 \%$, respectively.
\end{abstract}

\section{Introduction}

The productivity of sheep in many farms in different zones of the country has significantly increased as a result of a systematic improvement in the breed qualities of animals, feeding and housing conditions. However, the percentage of morbidity and mortality in sheep is still significant. One of the reasons for this lies in the fact that a number of large enterprises have not created conditions for keeping highly productive animals. They are forced to adapt to external conditions, which is associated with a decrease in the resistance of young animals to diseases [3-5].

The degree of influence of external stimuli on the body of lambs largely depends on the level of protective and adaptive mechanisms of the body. The task is to reduce the loss of young animals in the initial period of rearing by improving breeding work (obtaining genetically resistant animals with high immunobiological properties) [3-5].

The study of environmental factors associated with the transfer of sheep breeding to an industrial basis affecting the natural resistance of animals is also very important.

It should be noted that with expanded reproduction in the herd the proportion of ewes increased significantly. However, they and their offspring are kept in a common flock. The

\footnotetext{
* Corresponding author: getokov777@mail.ru
} 
consequence of this is pre-weaning mortality of the lambs, and ewes lag behind in development. Therefore, it is necessary to develop a technology for keeping first lambers and their lambs, which significantly increases the safety of young animals and the level of their natural resistance.

The aim of this work is to study the influence of genetic and environmental factors on the natural resistance of lambs and their safety.

We determined the indices of natural resistance of young animals depending on the age of mothers, the frequency of feeding with colostrum and the duration of lambing, as well as immunobiological indicators depending on the origin of the lambs.

\section{Material and research methods}

The work was carried out with sheep of the Caucasian breed and precoce in the "Shidginov" farm in the Kabardino-Balkarian Republic from 2015 to 2019. To study the age effect at the first mating on the safety of young ewes and the level of natural resistance of themselves and their offspring an experimental group of ewes at the age of 8.5-16 months and a control group of animals aged 19-20.5 months (100 heads each) were formed.

In the first year the animals of the experimental group were fed ad libitum (about $40 \%$ more than the VIZ standards). Sheep of the control group received food in accordance with the norms of the VIZh.

During the lambing period the level of natural resistance in the ewes and their offspring was determined by the content of immunoglobulins in the blood (nephelometric method), gamma globulins (electrophoresis method), total protein (biuret method). The bactericidal and lysozyme activity of blood serum was detected by the photonephelometric method.

The effect of the frequency and time of consumption of colostrum on the immunobiological reactivity of lambs obtained from mothers of the same age, matched according to the principle of analogs, was studied by bactericidal activity, lysozyme activity and by the content of immunoglobulins in blood serum. Blood was taken from lambs at the age of three and seven days. The influence of indoor microclimate on natural resistance was studied in 50 lambs, whose mothers were three-year-old ewes, selected according to the principle of analogues. The animals of the first group joined in at the beginning of the lambing campaign, the second - at the end of it. Blood was taken from lambs for research at the age of 10 and 20 days.

\section{Research results and their discussion}

We found that young ewes (9-16 months) with intensive rearing and abundant feeding have an average level of body resistance and its indicators are characterized by stability. The offspring obtained from these ewes (experimental group), in terms of the level of immune parameters, are not inferior to their peers obtained from the ewes of the control group (Table 1).

Table 1. Indicators of natural resistance of young animals months of age $(\mathrm{M} \pm \mathrm{m})$

\begin{tabular}{|l|c|c|c|c|c|}
\hline \multicolumn{1}{|c|}{ Group } & $\begin{array}{c}\text { Bactericidal } \\
\text { activity,\% }\end{array}$ & $\begin{array}{l}\text { Activity of } \\
\text { lysozyme, } \%\end{array}$ & $\begin{array}{l}\text { General } \\
\text { protein, } / 1\end{array}$ & $\begin{array}{c}\text { Immunoglobuli } \\
\text { n, mg / ml }\end{array}$ & $\begin{array}{l}\text { Gamma } \\
\text { globulin, } \%\end{array}$ \\
\hline Experienced & $62,4 \pm 4,5$ & $9,4 \pm 1,6$ & $72 \pm 5$ & $16,9 \pm 3,2$ & $28,9 \pm 4,9$ \\
\hline Control & $64,9 \pm 9,6$ & $9,0 \pm 2,1$ & $72 \pm 6$ & $16,7 \pm 4,1$ & $29,3 \pm 5,7$ \\
\hline
\end{tabular}


From the data in Table 1 it can be seen that lambs from lambing ewes in terms of lysozyme activity of blood serum, immunoglobulin content are superior to their peers from older ewes (the difference is statistically insignificant, $\mathrm{P}>0.05$ ). Young animals have the same vitality regardless of the age of their mothers. The lambs' mortality from birth to weanig in the experimental and control groups was approximately the same -7.2 and $8.0 \%$, respectively.

In terms of average daily gain (from birth to two months), the sheep of the control group surpassed their counterparts from the experimental group by only $6 \mathrm{~g}$. Later this difference is smoothed out. However, it should be borne in mind that if you use ewes who have not reached a live weight equal to $78 \%$ of the live weight of adult ewes then when two lambs are received, their fatness and immunity are sharply reduced which leads to the retention of the afterbirth and the death of animals.

During lactation such ewes in terms of bactericidal activity, lysozyme activity, immunoglobulin and total protein content fall behind older sheep by $50 ; 56 ; 90$ and $15 \%$, respectively (the difference is statistically significant in all cases). The offspring of these ewes was not viable, they had a low level of resistance (lambs' mortality exceeded $50 \%$ in 20 days after birth). To prevent lambs from dying, they should be weaned early and raised on sheep's milk replacer.

After the holding of lambs the natural resistance of the ewes increases, the effect of lactation on the general physiological state is smoothed out, and the good development of animals is ensured.

For two months of lactation lambing ewes, obsessed with twins, lose 6-8 $\mathrm{kg}$ of live weight, their bone tissue is deformed, which leads to a complete cessation of growth and development. When weaning one of the lambs, the loss of live weight is reduced to $2.5-3.5$ $\mathrm{kg}$. If both lambs are weaned off then an increase of 4.5-6.2 $\mathrm{kg}$ is observed which indicates good growth and development of the ewes. Lambs, when grown on sheep milk replacers, develop better than with the ewes. Their vitality and natural resistance increase although such lambs have a low average daily growth and immunobiological parameters in comparison with normally developed single lambs raised with ewes.

The general level of immunobiological reactivity of young animals, both during artificial rearing and during suckling, is significantly influenced by the amount of colostrum taken by lambs in the first hours after birth. As observations show in the first days of life with a lack of colostrum or its poor quality, the greatest mortality of young animals is noted. In this regard it is necessary to change the technology of keeping lambs from the first week after birth to 6 weeks of age.

We have found that the amount of immunoglobulins and other components in the first portion of colostrum, as well as the frequency of drinking it, are of decisive importance for the survival of lambs. This is due to the fact that the absorption of antibodies in the intestine is more active in the first 6 hours of a newborn's life and the permeability of unchanged immunoglobulins stops after 3 hours. In addition, in the first hours after lambing, the highest concentration of immunoglobulins is noted in colostrum. So, the first portion of colostrum contained $28.6 \mathrm{mg} / \mathrm{ml}$ of immunoglobulins, 1.5 hours after lambing - 16.4 and after 16 hours $-6.2 \mathrm{mg} /$ cell.

In lambs (experimental group) that sucked the mother during the first 10 minutes after birth and then repeatedly receiving colostrum in the first 6 hours, a higher level of immunoglobulins and bactericidal activity of blood serum is observed than in lambs (control group) who received colostrum after 30 minutes after lambing and with rare sucking of the mother in the first 6 hours. Thus, in the lambs of the experimental group, the content of immunoglobulins was $11.6 \%$, gamma globulins $15.7 \%$, the bactericidal activity of blood serum was $6.2 \%$ higher than in lambs control group. 
Subsequently, the lambs of the experimental group developed better than their peers (Table 2).

Table 2. Indicators of live weight and survival rate of young animals.

\begin{tabular}{|l|c|c|c|c|c|}
\hline \multirow{2}{*}{ Group } & \multicolumn{3}{|c|}{ Live Mass (Kg) } & \multicolumn{2}{c|}{ Safety (\%) } \\
\cline { 2 - 6 } & At birth & $\begin{array}{c}\text { In } 20 \\
\text { days. }\end{array}$ & $\begin{array}{c}\text { in } 60 \\
\text { days. }\end{array}$ & $\begin{array}{c}\text { in } 20 \\
\text { days. }\end{array}$ & $\begin{array}{c}\text { in } 60 \\
\text { days. }\end{array}$ \\
\hline Experimental & 3,2 & 6,9 & 14,1 & 91 & 86 \\
\hline Control & 3,3 & 6,5 & 13,2 & 75 & 68 \\
\hline
\end{tabular}

With insufficient consumption of colostrum in the first hours after birth, more than $25 \%$ of lambs die, and with timely and sufficient receipt of colostrum, their safety exceeds $90 \%$.

We found that under the same feeding conditions, lambs born at the beginning of the lambing campaign (group I) develop better than their peers born at the end of it (group II). They are also inferior to them in terms of safety and natural resistance (Table 3 ).

Table 3. Live weight gain, survival and natural resistance of lambs at 20 days of age $(\mathrm{M} \pm \mathrm{m})$

\begin{tabular}{|c|l|c|c|c|c|c|c|}
\hline Group & $\begin{array}{l}\text { Live } \\
\text { weight } \\
\text { gain, } \\
\mathrm{kg}\end{array}$ & $\begin{array}{c}\text { Storage, } \\
\%\end{array}$ & $\begin{array}{l}\text { Bactericidal } \\
\text { activity, \% }\end{array}$ & $\begin{array}{l}\text { Activity of } \\
\text { lysozyme, } \\
\%\end{array}$ & $\begin{array}{c}\text { Total } \\
\text { protein, } \\
\mathrm{g} / 1\end{array}$ & $\begin{array}{l}\text { Immunogl } \\
\text { obulin } \\
\mathrm{mg} / \mathrm{ml}\end{array}$ & $\begin{array}{c}\text { Gamma } \\
\text { globulin, } \\
\%\end{array}$ \\
\hline I & $3,6 \pm 0,4$ & 92,3 & $58,2 \pm 7,4$ & $10,4 \pm 0,9$ & $70,2 \pm 5$ & $15,8 \pm 2,4$ & $24,1 \pm 3,1$ \\
\hline II & $2,8 \pm 0,5$ & 73,1 & $46,3 \pm 6,8$ & $7,08 \pm 1,1$ & $69,4 \pm 7$ & $11,4 \pm 1,9$ & $17,9 \pm 3,2$ \\
\hline
\end{tabular}

Consequently, it is possible to reduce the mortality of lambs (by 10-15\%) significantly by lambing in a short time (cyclic insemination and group lambing) at sheep-breeding complexes.

With group lambing, the duration of the lambing campaign is 10-12 days. During this period the microclimate indicators slightly exceed normal requirements. In addition, after 20 days the animals are transferred to the lambing barn. Under normal lambing conditions despite a significant deterioration of the microclimate, the sheep are not driven to the shed until the last born lambs are 20 days old. Under these conditions even in the lambs obtained first, and their mothers, resistance and vitality deteriorate.

We also determined that the humoral factors of immunity are associated with the genetic characteristics of animals. Under the same conditions of keeping and feeding ewes with higher wool productivity surpassed in almost all immunological parameters their contemporaries with lower productivity (Table 4).

However, the differences in these parameters in the offspring of the ewes indicated in Table 4 are associated with different types of selection of parental pairs, which leads to an equalization of the productive and immune qualities of the compared lambs (the difference in all parameters is insignificant, $\mathrm{P}>0.05)$. At the same time, individual differences in immune parameters in lambs originating from ewes with unequal body defenses are traced.

Lambs born from ewes with high immune indices, at two months of age, surpass their peers obtained from low-resistant queens in bactericidal activity by $28 \%$, lysozyme activity by 24 , immunoglobulin levels by 18 and gamma globulins by $21 \%$ (the difference is significant in all cases).

The average daily gain in lambs with high immune parameters (from birth to two months) was $169 \mathrm{~g}$, or $35 \mathrm{~g}$ more than in young animals with low immune parameters. The survival rate of highly resistant stent lambs up to two months was $7 \%$ higher than that of low-productive peers. 
Table 4. Immune indices of ewea $(\mathrm{M} \pm \mathrm{m})$

\begin{tabular}{|l|c|c|c|c|c|}
\hline \multicolumn{1}{|c|}{ Group } & $\begin{array}{c}\text { Bactericidal } \\
\text { activity, \% }\end{array}$ & $\begin{array}{l}\text { Activity of } \\
\text { lysozyme, \% }\end{array}$ & $\begin{array}{l}\text { General } \\
\text { Protein g / 1 }\end{array}$ & $\begin{array}{c}\text { Immunoglobulin, } \\
\mathrm{mg} / \mathrm{ml}\end{array}$ & $\begin{array}{l}\text { Gamma } \\
\text { globulin, }\end{array}$ \\
\hline $\begin{array}{l}\text { Highly } \\
\text { productive }\end{array}$ & $71 \pm 4,2$ & $21,5 \pm 1,7$ & $75 \pm 6$ & $24,1 \pm 2,4$ & $29,7 \pm 3,9$ \\
\hline $\begin{array}{l}\text { Average } \\
\text { productivit } \\
\text { y }\end{array}$ & $68 \pm 5,6$ & $22,4 \pm 1,9$ & $73 \pm 6$ & $22,9 \pm 1,8$ & $27,2 \pm 2,8$ \\
\hline $\begin{array}{l}\text { Low- } \\
\text { productivit } \\
\text { y }\end{array}$ & $49 \pm 8,1$ & $16,4 \pm 1,4$ & $70,5 \pm 8$ & $16,3 \pm 2,1$ & $26,3 \pm 3,5$ \\
\hline
\end{tabular}

\section{Conclusion}

The analysis of the data presented shows the need for selection for the consolidation of hereditarily-determined high natural resistance through selection and selection of parental pairs, and also indicate that it is possible to directly influence the physiological reactions of the body, to increase the protective forces by changing the conditions of keeping and feeding, using optimal technology of keeping, corresponding to the biological characteristics of animals.

\section{References}

1. I.A. Pomitun, N.A. Kosova, Scientific and technical. Bull. Institute of Animal Breeding of the National Academy of Sciences of Ukraine, 107, 110-114 (2012)

2. V.V. Terent'ev, O.V. Maksimova, Agricultural science, 5, 17-18 (2004)

3. A.N. Ulyanov, A.Ya. Kulikova, O.G. Grigorieva, Sheep, goats, wool business, 3, 54-60 (2011)

4. Yu.I. Galtsev, E.A. Lakota, O.A. Vorontsova, Sheep, goats, wool business, 1, 16-17 (2012)

5. I.E. Turduev, M.S. Narymbetov, Reports of the Tajik Academy of Agricultural Sciences, 4 (38), 55-58 (2013) 